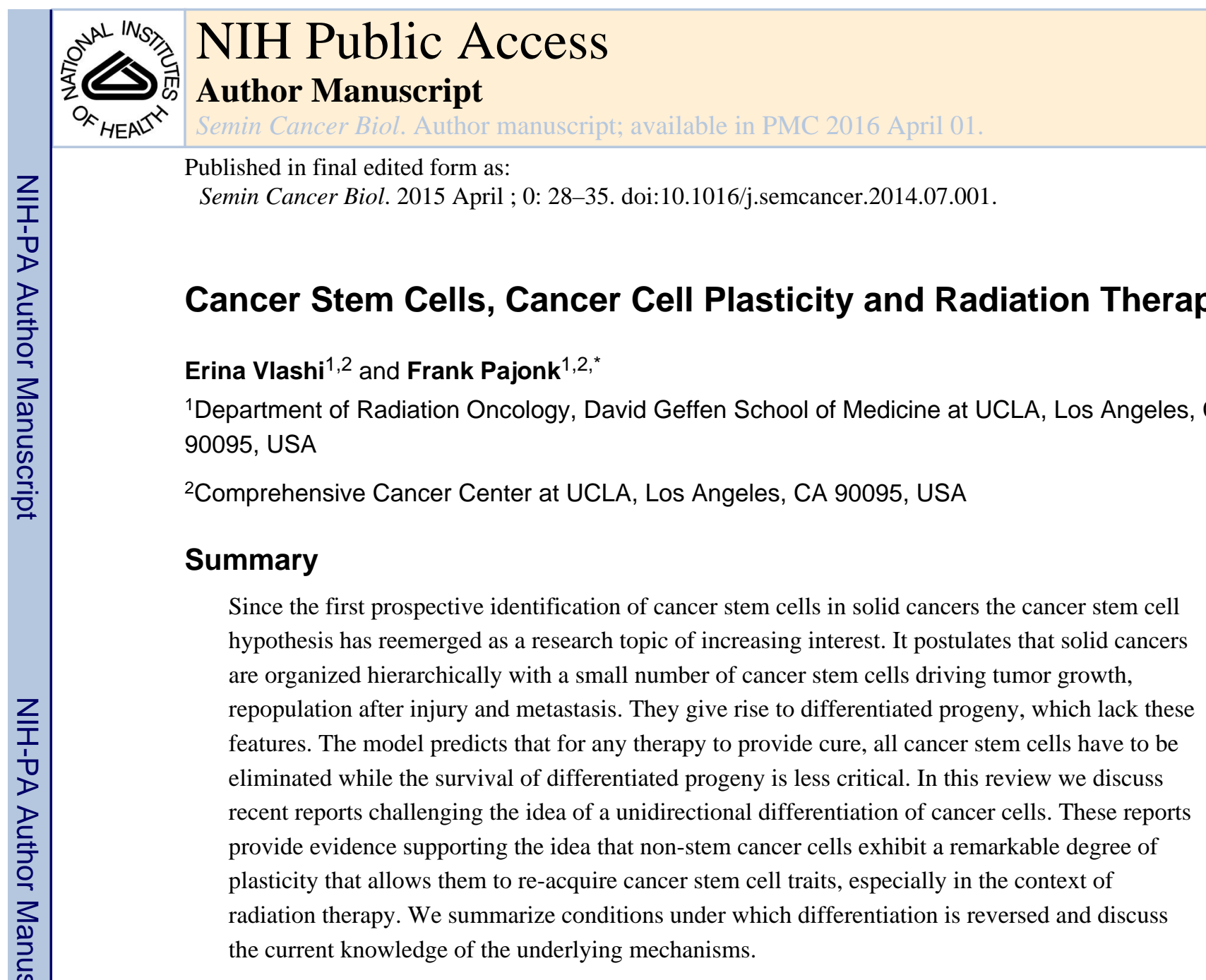

Keywords

Cancer stem cells; reprogramming; radiation therapy

\title{
Introduction
}

In 2010, the estimated medical costs of cancer care in the United States exceeded \$124 billion (source: National Cancer Institute). Yet, despite the enormous spending for cancer care, many cancers are still fatal and 5-year survival rates have not significantly changed over the decades. This raises the question as to whether current radiation treatment approaches can be technically further fine-tuned to improve cancer cure rates, or if cancer therapy in general needs a paradigm shift to substantially improve future outcome.

\footnotetext{
(c) 2014 Elsevier Ltd. All rights reserved

"Correspondence address: Department of Radiation Oncology, Division of Molecular and Cellular Oncology, David Geffen School of Medicine at UCLA, 10833 Le Conte Ave, Los Angeles, CA 90095-1714, pajonk@ucla.edu.

Publisher's Disclaimer: This is a PDF file of an unedited manuscript that has been accepted for publication. As a service to our customers we are providing this early version of the manuscript. The manuscript will undergo copyediting, typesetting, and review of the resulting proof before it is published in its final citable form. Please note that during the production process errors may be discovered which could affect the content, and all legal disclaimers that apply to the journal pertain.
} 
Aside from surgery, other current standard cancer therapies, such as radiotherapy, chemotherapy, and most targeted therapies have been designed, developed and evaluated for their effectiveness based on bulk tumor responses. This approach for developing novel anticancer therapies continues to be widely applied despite our broad knowledge of the undisputable heterogeneity of human tumors. It has been known for over a century that tumors exhibit a remarkable phenotypical heterogeneity, which extends to their radiosensitivity, drug resistance and genetic alterations of the individual cells composing a tumor mass. Employing bulk tumor responses as the primary end point for determining the effectiveness of novel treatments is certainly a very practical approach. However, such an approach will only be successful in yielding cures if the response of the bulk tumor represents the response of the most resistant subpopulation of cells within the heterogeneous tumor and this might hold true for only some cancers like advanced melanoma.

In this review we hope to add to the ongoing discussions about clinically relevant tumor heterogeneity and its potential roots $[1,2]$. We will focus on the effects of ionizing radiation on the heterogeneity of solid tumors in the context of competing models of tumor organization, the cancer stem cell hypothesis and the clonal evolution model.

\section{The Cancer Stem Cell Hypothesis}

The cancer stem cell (CSC) concept was first formulated in the 1800s, and has its roots in Rudolf Virchow's Cellular Pathologie [3], and a case report by Julius Cohnheim in 1875 [4]. A seminal paper by Steven Paget in 1889 first gave rise to the "seed and soil hypothesis" for cancer, hypothesizing that cancer cells within a tumor have the intrinsic capability to "seed" a metastasis in a distant organ that has favorable conditions for secondary tumor growth (soil) [5]. In 1961 Pierce and Speers proposed that tumors are caricatures of normal tissue development, thus formulating a hierarchical model for the development and propagation of cancer [6]. However, it took more than 100 years since Rudolf Virchow's article to validate the cancer stem cell hypothesis. In 1994, Dick and colleagues for the first time prospectively isolated leukemia stem cells [7], which not only confirmed the heterogeneity of cancer cells in this cancer, but also gave rise to the hypothesis that tumors are organized in a hierarchical manner. It took another 10 years until marker profiles for highly enriched cancer stem cell populations in solid cancers could be defined $[8,9]$.

According to the CSC hypothesis, cancers mirror the hierarchical organization of normal tissues with a small number of cancer stem cells at the apex of this hierarchy. In this model, the ability to initiate tumors and to give rise to the heterogeneous cell populations found in the original tumor is exclusively attributed to the CSC population with all of their differentiated progeny lacking these features $[10,11]$. In analogy to normal tissue development, the idea of hierarchy and differentiating progeny suggests that epigenetic changes and signaling events regulate the structural organization of a tumor during differentiation events, which are in general believed to be unidirectional.

After the initial description of brain cancer stem cells in 2001 [10, 11], cancer stem cells were identified in breast cancer [12], and melanoma [13] a few years later. Today, cancer stem cell populations continue to be identified and isolated from a growing list of solid 
cancers. The presence of CSCs in these different tumor models is generally confirmed by operational means, demonstrating increased tumorigenicity and pluripotency of a subset of cancer cells prospectively isolated from the bulk of the tumor. The gold standard of operational assays for demonstrating a CSC phenotype is the in vivo limiting dilution assay using immune-compromised animals [10, 11]. In 2008, the concept of CSCs in solid cancers was challenged when the Morrison lab demonstrated that in advanced melanoma CSC frequencies ranged from 1 in 2 to 1 in 8 cells if NOD/SCID interleukin- 2 receptor gamma chain null $\left(\mathrm{Il}_{2 \mathrm{rg}^{-/}}\right)$(NSG) mice were used for the in vivo limiting dilution assays and Matrigel was mixed with the implanted cancer cells [14]. These results were interpreted to suggest that no CSCs exist in melanoma. Recognizing the possibility that some metastatic melanomas may have very high frequencies of tumorigenic cells, a follow-up study by the Weissman lab, characterized CD271 ${ }^{+}$as an alternative CSC marker in melanoma. The authors prospectively isolated melanoma stem cells as a population in $\mathrm{CD} 271^{+}$melanoma cells occurring at a frequency of $\sim 16 \%$ of the total cell population [15]. While cancer stem cells may be a common occurrence in advanced and metastatic melanoma cases, a more recent report by Ishizawa et al. confirmed the low frequency of CSCs in a panel of human pancreatic, non-small cell lung and head and neck carcinomas. This study also confirmed the increased tumorigenicity of CSCs derived from these tumors in both NOD/SCID and NSG immune-deficient mouse models [16]. Taken together with the Weissman report on melanoma, the Ishizawa study suggested that advanced melanomas should not be used as pars pro toto for all solid cancers, as an example against the CSC hypothesis.

It is noteworthy to point out that no population of cells exhibiting all the agreed-upon properties of CSCs has yet been isolated, therefore we will discuss below an alternative model for initiation and propagation of cancer, the "clonal evolution model".

\section{The Clonal Evolution Model}

The clonal evolution model of cancer is an alternative model for the organizational structure of tumors initially described by Peter Nowell in 1976 [17]. Similar to the cancer stem cell hypothesis, the model assumes a clonal origin of cancers with the important distinction that it does not propose a hierarchical organization for tumors. The clonal evolution model postulates that the genetic instability of cancer cells leads to different clones of cells that contribute to the cellular heterogeneity of cancers; in turn, subsequent acquisition of additional mutations that favor cellular proliferation generate cells that outcompete other cell populations and become the driving cell population in a tumor $[2,17]$. Taking into account the stochastic nature of acquiring additional genetic mutations, this model predicts that every cell in a tumor can acquire cancer stem cell traits through genetic changes, rather than epigenetic modifications. There is indisputable evidence supporting the genetically unstable nature of solid cancers and its contribution to the genetic heterogeneity of solid tumors, even if tumors originate from specific cell clones [18-20]. What is less clear is whether stem cell traits are shifting from one clone to another in a stochastic manner. There is evidence that the clonal evolution model may hold true for some cancers however, a growing body of scientific evidence supports a hierarchical model for the majority of solid tumors [21]. For example, a recent study by Penny et al. looked at Gleason grade progression and found that even though PSA screening leads to a significant decrease of advanced prostate cancers, the 
Gleason grade did not follow this trend very closely, suggesting that in the vast majority of prostate cancers the most aggressive cell population arises early during cancer development [22].

\section{Cancer Stem Cell Markers}

The CSC hypothesis and the clonal evolution model are not necessarily mutually exclusive. Both models agree on the existence of a subpopulation of cells with increased tumorigenicity in solid cancers. However, a disagreement arises from these models on whether the tumorigenic population of cells within a tumor is static and rare and exhibits stem cell traits, or whether increased tumorigenicity is a transient feature of competing cell populations that shifts from one cell population to another during the malignant progression of a cancer. Such a distinction is crucial in determining whether novel therapeutics specifically targeting CSCs would ultimately lead to cures.

As outlined earlier, the presence of stem cell markers on a subpopulation of cancer cells does not confer a CSC phenotype to that population. Instead, operational assays are necessary to confirm the functional CSC phenotype of the putative population. However, the detection of a variety of cell surface proteins has been successfully applied as surrogate markers for prospective identification of cell populations highly enriched for cells that fulfill the functional definition of CSCs. The first marker used for enriching CSCs in human solid tumors was CD133 (prominin-1), a five-transmembrane glycoprotein with incompletely understood biology [23]. Detection of two glycosylated epitopes, AC133 and AC141 could enrich for CSCs in brain tumors [8, 9, 11]. However, CD133 has been questioned as a reliable CSC marker for a variety of reasons, ranging from the specificity of anti-CD133 magnetic beads [24], to reports claiming that CD133 is solely a marker for bioenergetic stress [25], and others reporting that in some gliomas both, $\mathrm{CD} 133^{+}$and $\mathrm{CD} 133^{-}$cells fulfill the definition of CSCs [26]. Furthermore, in embryonic stem cells, colon cancer and melanoma, AC133 fluctuated with progression through the cell cycle, with cells in the $\mathrm{G}_{0} / \mathrm{G}_{1}$ phase of the cell cycle expressing the lowest levels of this epitope [27]. Nonetheless, despite the above-listed caveats, high level of CD133 expression has been used to identify and isolate a highly radioresistant and highly tumorigenic subpopulation of glioma cells from fresh human specimens. In these insightful mechanistic studies, the radioresistance was attributed to hyper-phosphorylation of cell cycle checkpoint kinases and increased DNA repair in glioblastoma CSCs [28]. Importantly, the expression of CD133 in clinical tumor specimen predicted adverse clinical outcome for glioma patients [29, 30]. Aside from glioma, CD133 expression has been used to enrich for CSCs in other solid cancers including hepatocellular carcinoma cell lines [31], human prostate cancers [32], human melanoma [22], and many others. However, the evidence in other tumor entities is less compelling and more controversial than in glioma.

In breast cancer, a marker combination of $\mathrm{CD} 24^{-/ \mathrm{low}} / \mathrm{CD} 44^{\mathrm{high}} / \mathrm{ESA}^{+} / \mathrm{Lin}^{-}$enriched for CSCs in luminal breast cancers [12]. CD24-/low/CD44 ${ }^{\text {high }}$ breast CSCs were shown to be highly radioresistant due to efficient free-radical scavenging in breast CSCs [33]. Using a panel of established breast cancer cell lines, Fillmore and Kuperwasser demonstrated that breast cancer cell lines do contain CSCs. However, they also found that the CD24-/low/ 
CD44 ${ }^{\text {high }}$ marker combination identified cells with a CSC phenotype in only a subset of breast cancers, and did not correlate with tumorigenicity in basal breast cancer cell lines [34].

CD44 ${ }^{\text {high }}$ has been reported to identify a cell population enriched for CSCs in head and neck squamous cell carcinomas (HNSCC) [35], however due to the ubiquitous expression of CD44 in this tumor entity these results are discussed controversially [36, 37].

The expression and activity of aldehyde dehydroxygenase (ALDH) appears to be a more robust marker for CSCs. ALDHs are a family of 18 isoenzymes expressed in humans.

ALDH1 is one of the four vertebrate retinaldehyde dehydrogenases and oxidizes retinal to retinoic acid. Initially, ALDH1 was reported to be elevated in $\mathrm{CD} 34^{+}$hematopoietic progenitor cells [38]. Ginestier and colleagues identified ALDH1 activity and expression as a CSC marker for breast cancer and demonstrated that CD24-/low/CD44high/ALDH1 ${ }^{+}$breast cancer cells could form tumors from as few as 20 cells. More importantly, high ALDH1 expression was associated with a poor clinical prognosis [39]. A follow-up study could not confirm these results and suggested that ALDH1 expression is associated with a basal and Her2-positive phenotype and that ALDH1 expression in cancer cells does not correlate with outcome. Interestingly, the latter study reported that high ALDH1 expression in the stromal cells correlated with superior outcome in triple negative patients [40]. A more recent report demonstrated that the ALDH1A3 isoenzyme is the major source of ALDH1 activity in breast cancer stem cells [41] bringing into question the specificity of the antibodies used for the different isoforms of ALDH1. This study may explain some of the conflicting results from different laboratories. Aside from breast cancer, ALDH1 activity is widely used as a marker for CSCs in other solid tumors including head and neck squamous cell carcinoma (reviewed in [42]), colorectal cancer [43], and lung cancer [44].

In addition to CD133, CD24-/low/CD44high, and ALDH1 marker systems, additional surface CSC markers have been identified in melanoma [13] and prostate cancer [45]. Our own laboratory discovered that subpopulations of cells in glioma, breast cancer, and HNSCC with reduced activity of the $26 \mathrm{~S}$ proteasome are enriched for CSCs [46, 47]. The lack of activity is based on a concerted down-regulation of proteasome subunit mRNAs caused by binding of Musashi1 to the 3'-UTR of the mRNA coding for the NF-YA subunit of the tetrameric transcription factor NF-Y [48], the master regulator of basal proteasome subunit expression in mammalian cells [49]. We have exploited this discovery to establish an imaging system for CSCs based on a fusion protein between a reporter protein and the Cterminal degron of murine ornithine decarboxylase (cODC). This unique reporter system for CSCs allows for identification, tracking and isolation of CSC populations over time without further manipulation of cells, in vitro and in vivo [46]. Other laboratories have employed our reporter system to identify CSC in lung cancer [50], pancreatic cancer [51] and hepatocellular carcinoma [52]. In breast cancer, cells with low proteasome activity partially overlap with $\mathrm{ALDH} 1^{+}$and $\mathrm{CD} 24^{\text {low/-}} / \mathrm{CD} 44^{\text {high }}$ cells [53]. In glioma, cells with low proteasome activity express Sox2, Nestin, and Musashi-1 [46]. Most importantly, lack of proteasome subunit expression correlated with inferior survival in glioblastoma [54], HNSCC [47] and breast cancer patients [55]. 
It is important to emphasize at this point that none of the marker combinations reported in the literature to date are sufficiently specific to prospectively identify individual CSCs. Instead, they only enrich for CSCs populations. Therefore, in vivo limiting dilutions assays remain the gold standard for estimating CSCs frequencies.

\section{Stem cells factors and plasticity}

The stem cell state of pluripotent normal stem cells is governed by stem cell factors, which become silenced during differentiation as a consequence of DNA methylation and chromatin remodeling. This process is reversible and transfection of somatic cells with the four Yamanaka factors Sox2, Oct4, Klf4, and c-Myc [56] generates induced pluripotent stem (iPS) cells. All four transcription factors are wired in an incompletely understood network with Nanog, a unique set of transcription factors, Poly-comb complexes, microRNAs and histone modification enzymes to allow for a unique permissive chromatin state for reprogramming events to occur (reviewed in [57]). It is noteworthy that the Oct4 [58], Sox2 [59], Klf4 [60], c-Myc [61], and Nanog [62] are all substrates of the 26S proteasome and thus, spared from degradation in putative CSCs that lack proteasome activity.

Oct4 (also known as POU5F) is a homeodomain transcription factor involved in early embryonic development and pluripotency [63] through stabilization of higher-order chromatin structure of the Nanog locus [64]. The expression of Oct4 in cancer cells, outside the context of teratoma, and in differentiated cells has been discussed controversially due to the existence of several transcribed pseudogenes of Oct4 with unknown function. These pseudogenes can lead to false-positive RT-PCR results [65], and unreliable Western blotting and flow cytometry [66]. While these are valid concerns, a growing number of publications report Oct4 expression (and therefore, most likely expression of its pseudogenes) as predictors of adverse clinical outcome in cancer, thus suggesting a functional role for Oct4 (and/or its pseudogenes) in solid cancers. For example, de Resende and coworkers reported shortened biochemical progression-free survival in prostate cancer patients with Oct $4 \mathrm{~A}^{+} /$ Oct $4 \mathrm{~B}^{-}$tumors using a monoclonal antibody considered to specifically recognize the first 134 amino acids of Oct4A [67]. A study by Koukourakis et al., found cytoplasmic expression of Oct 4 to be correlated with local control in head and neck cancer patients after chemo-radiotherapy. In the latter study, the antibody used was raised against the C-terminal epitope of Oct 4 , and, if the cytoplasmic staining pattern is taken into consideration, this antibody most likely only recognized Oct4B [68]. Using the same specific antibody for Oct4A as de Resende et al., Zhang and colleagues found the expression of Oct4A to be inversely correlated with the survival of patients with adenocarcinoma of the lung [69]. In another study on rectal cancer, Salgusa et al. used a non-specific antibody against Oct4 and found cytoplasmic staining and thus, most likely Oct4B expression to be correlated with distant failure [70]. In summary, a growing body of literature points to a possible role of Oct4 expression in solid tumors. The function of Oct4, and its expression patterns of splicing isoforms and pseudogenes remain to be studied in more detail.

Sox2 (SRY [sex-determining region Y)-box 2] is a HMG-box transcription factor that hetero-dimerizes with Oct4. Similar to Oct4, Sox2 is essential for pluripotency in ES cells [71] and for acquired pluripotency in iPS cells [72]. Sox2 is highly expressed in neural stem 
cells in the subventricular zone and the dentate gyrus of the central nervous system. In mice it is a marker for stem cells in the stomach, duodenum, cervix, anus, testes, lens, and multiple glands. Sox 2 seems to be the only stem cell factor commonly expressed in ES cells, fetal progenitor cells and adult stem cells [73]. In neural stem cells, Sox2 regulates selfrenewal through expression of the intermediate filament nestin [74]. Deregulated Sox2 expression in tumor cells has been described by several groups and in different tumor types including gastric cancer [75, 76], breast cancer [77], pancreatic cancer [78], brain tumors [79] and lung cancer [80].

Krüppel-like factor 4 (Klf4) is a zinc-finger-containing transcription factor first described in the gut [81] and in the skin [82]. The downstream events of Klf4 signaling are contextdependent allowing Klf4 to act as a tumor suppressor in the colon [81] and gastric epithelium [83], and as an oncogene leading to breast cancer [84] and squamous cell carcinoma of the skin [85]. When used to reprogram somatic cells into iPS cells, the role of Klf4 is incompletely understood. However, its anti-apoptotic effects have been suggested to contribute to reprograming. It is noteworthy that Klf4 is dispensable for reprogramming somatic cells into pluripotency, and together with c-Myc it can be replaced by Nanog and LIN28 [86]. Many of the target genes of Klf4 are involved in cell cycle control [87]. Klf4 inhibits cell proliferation by inhibiting cells to transition from the G1- to the S-phase of the cell cycle [88]. In response to DNA damage, Klf4 facilitates arrest of the cells in the G1/S checkpoint in a p53-dependent manner and maintains the $\mathrm{G}_{2} / \mathrm{M}$ checkpoint of the cell cycle.

The c-Myc oncogene is a member of the family of basic helix-loop-helix leucine zipper transcription factors. In pluripotent stem cells c-Myc is downstream of LIF/STAT3 signaling and acts as a universal amplifier of gene expression. While c-Myc seems to be dispensable for the reprograming of somatic cells it greatly enhances the efficiency of the remaining Yamanaka factors to induce a pluripotent state [72].

The ability of CSCs to self-renew and give rise to more differentiated cell types found in a tumor defines the CSC state. However, it is not clear which molecular pathways govern the CSC state and signaling requirements most likely vary between different tumor entities and even within subpopulations of cells of the same tumor type. For example, Suva et al. recently reported that expression of the neurodevelopmental transcription factors POU3F2, SOX2, SALL2, and OLIG2 was sufficient for the generation of a glioma stem cell phenotype [89]. The functional contribution of many of the markers used to identify CSCs is only incompletely understood, and a number of them, such as CD133, may only be surrogate markers without a functional link to the CSC state.

The existence of a cancer cell subpopulation inside of a tumor with functional properties of CSCs has important implications for clinical anti-cancer therapy. The demonstrated inherent chemo- and radioresistance $[28,33,90]$ of CSC populations make them the prime target for any anti-cancer therapy. Importantly, we [54] and others [29, 39] have shown that the number of CSCs in breast cancers and glioma, present at the time of treatment, is inversely correlated with clinical outcome [91]. These observations imply that the existing number of CSCs in a tumor is one of the most important constraints for the curability of a patient. Indeed, initial reports have suggested that radiation preferentially kills non-tumorigenic 
cells, thereby enriching for CSCs [28, 33, 92]. However, follow-up studies revealed that the absolute increase in breast CSC numbers detected after exposure to ionizing radiation could not easily be explained by preferential killing of non-tumorigenic cells [53, 93]. In earlier reports, Erenpreisa and colleagues observed up-regulation of embryonic transcription factors Sox2, Oct4, and Nanog in p53-mutated lymphoma cells in response to irradiation [94]. The up-regulation of the transcription factors coincided with radiation-induced polyploidy and the authors concluded that increased gene dose in polyploid cells was sufficient to express Sox2, Oct4, and Nanog at levels beyond the necessary threshold to induce a CSC state. Our own work in breast cancer did not show dependence of this process on p53 mutations, but did confirm radiation-induced preferential up-regulation of Sox2, Oct4, Klf4, and Nanog in polyploid cells, as well as increased expression of these transcription factors if polyploidy was induced pharmacologically [53]. More importantly, our data demonstrated that radiation-induced expression of these factors reprogrammed non-tumorigenic cancer cells and led to acquisition of functional CSC traits in vivo [53], offering an explanation for the significant increase in the absolute number of breast CSCs after radiation therapy. A recent study by Ghisolfi et al. confirmed radiation-induced up-regulation of Oct $3 / 4$ and Sox 2 and acquisition of a CSC phenotype in two hepatocellular carcinoma cell lines [95].

\section{Effect of tumor microenvironment on CSCs plasticity}

As summarized above new evidence is emerging supporting the phenomenon of spontaneous and therapy-induced reprogramming of cancer cells into CSCs. The number of these studies is still small; nonetheless they have begun to uncover the mechanism behind the conversion of cancer cells into CSCs. In the case of radiation-induced reprogramming, the re-expression of stem cell factors correlates with the reprogramming events. Although radiation-induced reprogramming of non-stem cells into CSCs is readily observed in vitro [53], the in vivo scenario may be a more complex network of micro-environmental signals.

In the normal stem cell field extensive effort has been applied to reprogram terminally differentiated somatic cells into pluripotent stem cells, which was rewarded in 2006 when Takahashi and Yamanaka successfully reprogrammed mouse somatic cells into induced pluripotent stem cells by the transduction of only four transcription factors [72]. However, it has been known for many years that reprogramming/dedifferentiation of differentiated cells in vivo can happen spontaneously in the absence of exogenous reprogramming factors under the right micro-environmental conditions, as summarized in a recent review [96]. Normal tissue non-stem cells, and their malignant counterparts, have the ability to spontaneously convert into a normal tissue stem cell or CSC state [97]. These observations suggest that the process of differentiation is not unidirectional. A recent report demonstrated the conversion of differentiated broncheo-alveolar epithelial cells into epithelial stem cells upon viral infection or chemical injury in vivo [98]. Furthermore, Shaykhiev et al. reported an embryonic stem cell gene expression signature for lung stem/progenitor cells in healthy smokers, which suggests the possibility that acquisition of genetic mutations cooperate with a stress-induced stem cell state to initiate malignant growth [99].

The tumor microenvironment is composed of a variety of cell types, including cancer associated fibroblasts (CAFs), immune cells, endothelial cells lining the tumor vasculature 
and extracellular matrix components, among others [100]. For most solid cancers, the CSC niche is currently undefined and the supporting signals for a multi-potent CSC state have not yet been unveiled. However, in brain cancers it has been shown that CSCs preferentially reside in relatively well-oxygenated perivascular niches inside the tumor [101]. Interestingly, endothelial cells express both, CXCL12/SDF1 [102] and Notch ligands [103], which cause chemotaxis towards tumor blood vessels and promote self-renewal in glioma [104], which may hold a druggable target against CSCs. A second, hypoxic niche for glioma cells was described by Jeremy Rich's laboratory [105]. Importantly, hypoxic conditions resulted in reprogramming of CD133-negative glioma cells into CD133-positive cells with a CSC phenotype. These reprogramming events coincided with increased Oct4, Nanog, and cMyc expression [105]. The same group later reported that exposure of non-stem glioma cells to low $\mathrm{pH}$, frequently found in hypoxic tumors also mediated the acquisition of a CSC phenotype [106].

The above studies demonstrate an apparent preference for localization of CSCs within the tumor microenvironment, thus defining a CSC pseudo-niche. Alternatively, these observations could suggest that the CSC state is not a cell autonomous process, but rather dictated by the tumor microenvironment. In some elegant studies Vermeulen et al. demonstrated that the CSC state of Wnt-activated colon cancer cells was dependent on activation by stromal-derived hepatocyte growth factor (HGF) present in the tumor microenvironment [107]. In a different study Giannoni et al. uncovered the importance of IL-6 in activating tumor-associated fibroblasts, which in turn induced EMT and stemness in prostate cancer cells [108]. In support of these studies, Iliopoulos et al. identified IL-6 as the mediator responsible for converting non-stem cancer cells into CSCs in patient-derived breast cancer specimen and breast and prostate cancer cell lines [109]. A dynamic equilibrium was observed between CSCs and their progeny, resulting in a constant ratio between both cell populations over many passages. Ohanna et al. confirmed these findings reporting that the secretome of melanoma cells entering senescence after chemotherapy induced a CSCs phenotype in non-stem melanoma cells [110]. Taken together, these data suggest that differentiation in normal tissues and cancers is directed, but not unidirectional. There is now clear experimental evidence strongly suggesting that non-stem cells can revert to a stem cell state to compensate for cell loss in the stem cell compartment in a normal or malignant tissue. Most importantly, these studies strongly support the idea that cancer stem cell plasticity, a phenomenon now observed by many labs to occur spontaneously, or in response to therapy, is tightly regulated by the tumor microenvironment.

Clinical radiation therapy applied in daily fractions of $2 \mathrm{~Gy}$ from different directions with the tumor mass at the center, effectively controls tumor growth while sparing normal tissues. Still stromal cells inside or adjacent to the tumor, such as cancer-associated fibroblasts (CAF) receive considerable amounts of radiation, which can affect their interaction with cancer cells. Although the molecular pathways remain to be elucidated, collectively, most literature highlights the pro-malignant phenotype acquired by CAFs after radiation exposure $[111,112]$. Therapy-induced changes in the tumor stroma may play a crucial role in ultimately determining the degree of phenotypic plasticity of cancer cells by specific therapies. Ionizing radiation generates waves of primary and secondary reactive oxygen species in cells, with the latter persisting for weeks and months after the irradiation event. 
The late responses to radiation treatment can have an effect on lipids, proteins and most importantly DNA $[113,114]$. Such events give rise to a pro-inflammatory microenvironment characterized by increased expression of TNFa, pro-inflammatory interleukins and interferon- $\gamma[113,114]$ and consequently activation of downstream STAT3 signaling, which is known to promote self-renewal in embryonic stem cells [115].

Epithelial-to-mesenchymal transition (EMT) and its reverse process, mesenchymal-to epithelial transition (MET) are essential cellular transitions during embryonic development. A plethora of scientific evidence has also implicated these two processes (EMT and MET) in tumor development and metastasis. EMT is regulated by a variety of different pathways including proinflammatory signals like NF- $\kappa \mathrm{B}$ and TGF- $\beta$ signaling. Interestingly, these pathways are activated in response to irradiation.

The Wicha laboratory recently reported that breast cancers have two different pools of CSCs: (1) an ALDH1-positive population with an epithelial phenotype found in hypoxic areas of a tumor and (2) a CD24-/CD44+ population of cells at the invasive front of the tumor exhibiting a mesenchymal phenotype. Their study provided convincing evidence that both populations could convert into each other via EMT/MET transitions [116]. Unfortunately, the study did not address if cells from the bulk tumor population, lacking both the ALDH1-positive and the CD24-/CD44+ phenotype, could convert into a CSC and if this process was also mediated by EMT/MET.

\section{Concluding remarks}

For most cancers, survival rates have remained unchanged for decades and systemic disease is almost always fatal. Experimental and clinical data provide a growing body of evidence supporting the hierarchical organization of cancers with a small number CSCs able to selfrenew, repopulate a tumor after treatment and initiate metastatic growth. The resistance of CSCs to chemotherapy and their relative resistance to radiotherapy explain why macroscopic tumor response to anti-cancer treatments is not a robust predictor for clinical outcome. Yet, most established chemotherapies, including targeted therapies, have been and continue to be developed based on their effects on bulk tumor cell populations despite the knowledge that responses of the bulk tumor cell populations are unable to predict effects on the CSC population. It is worth noting that proliferation is a prerequisite for most chemotherapeutics, as well as radiation therapy to be effective and that any senescent and quiescent (non-CSCs) cells would also be resistant to these therapies. Interestingly, we found that about one third of the CSC population in established glioma and breast cancer cell lines were in a quiescent state and were recruited into the cell cycle after irradiation [46, 93]. In contrary, non-tumorigenic cells entered a senescent state after exposure to radiation [93]. While senescent cells have a finite life span and would not contribute to tumor relapse, a rare population of quiescent cells without stem cell characteristics (i.e. self-renewal, tumorigenicity) could eventually terminally differentiate and not contribute to tumor relapse or acquire CSC traits.

The discovery of marker profiles for the prospective identification of CSCs has led to a renaissance of the CSC hypothesis, and has reinvigorated the hope of identifying novel 
treatments that specifically target CSCs. However, the growing number of reports suggesting a remarkable plasticity of the non-stem cell population adds an additional layer to the already complex picture of treatment responses of cancer cells. Understanding the underlying mechanisms could hold the key for improving the efficacy of chemotherapy and radiation treatment in the future. The role of the tumor microenvironment on the reprogramming of cancer cells has not been fully established, however the existing data suggests that modifying the tumor microenvironment (i.e. IL-6 depletion) during treatment may also offer therapeutic benefit. It will be very important that future studies shed more light on the role of the tumor microenvironment on therapy-induced reprogramming and plasticity of cancer cells. Deeper insight into this phenomenon will be very important in enhancing future anti-cancer therapies.

Recent data on the prospective identification of CSCs supports the CSC hypothesis with a hierarchical organization of tumors $[9,11,12]$. However, it also highlights the phenotypical plasticity of cancer cells in support of the clonal evolution model [14]. While the classic clonal evolution model describes acquisition of CSC traits as a stochastic process, recent studies indicate that this process is not random, especially in response to cellular injury as seen after radiation therapy [53]. This has important clinical implications for radiation therapy. The CSC hypothesis predicts that a drug that targets CSCs specifically would lead to improved outcome or even cure with no real need for radiation therapy since all progeny lack the ability to repopulate the tumor and would eventually die or enter senescence. The response predicted by the clonal evolution model is more complex, as every cancer cell could acquire CSC traits over time through acquisition of a diverse set of mutations and many of these clones would most likely escape a drug with a limited scope of molecular targets thus, indicating the need for radiotherapy.

The observation that radiotherapy as well as chemotherapy are driving forces in the acquisition of an induced CSC phenotype suggest that this dedifferentiation step is less random and rather a direct response of the cancer cell population to treatment. Importantly, when the rate at which a treatment-induced, treatment-refractory CSC phenotype is acquired, exceeds the rate of cell killing, cure becomes impossible. Conversely, drugs that interfere with treatment-induced reprogramming may significantly improve the efficacy of the therapy with only few or no side effects, as opposed to classic anti-cancer agents in the past, which added little therapeutic benefit while contributing significantly to the increased toxicity of combined treatments. Spontaneous, as well as therapy-induced reprogramming of cancer cells is most likely subject to complex negative and positive feedback regulation and it remains to be investigated if the molecular mechanisms that underlie therapy-induced reprogramming are unique to cancer or if normal tissue damage repair employs the same pathways before it can be determined if this phenomenon has druggable targets with a therapeutic window.

\section{Acknowledgments}

FP was supported by a generous gift from Steve and Cathy Fink and grants from the National Cancer Institute (RO1CA137110, 1R01CA161294) and the Army Medical Research \& Materiel Command's Breast Cancer Research Program (W81XWH-11-1-0531). 


\section{References}

1. Marjanovic ND, Weinberg RA, Chaffer CL. Cell plasticity and heterogeneity in cancer. Clinical chemistry. 2013; 59(1):168-179. [PubMed: 23220226]

2. Greaves M, Maley CC. Clonal evolution in cancer. Nature. 2012; 481(7381):306-313. [PubMed: 22258609]

3. Virchow R. Cellular-Pathologie. Archiv für pathologische Anatomie und Physiologie und für klinische Medicin. 1855; 8(1):3-39.

4. Cohneim J. Congenitales, quergestreiftes Muskelsarkom der Nieren. Virchows Archiv für Pathologische Anatomie und Physiologie und für Klinische Medizin. 1875; 65(1):64-69.

5. Paget S. The distribution of secondary growths in cancer of the breast. Lancet. 1889; 1:571-573.

6. Pierce GB, Speers WC. Tumors as caricatures of the process of tissue renewal: prospects for therapy by directing differentiation. Cancer research. 1988; 48(8):1996-2004. [PubMed: 2450643]

7. Lapidot T, Sirard C, Vormoor J, Murdoch B, Hoang T, Caceres-Cortes J, Minden M, Paterson B, Caligiuri MA, Dick JE. A cell initiating human acute myeloid leukaemia after transplantation into SCID mice. Nature. 1994; 367(6464):645-648. [PubMed: 7509044]

8. Hemmati HD, Nakano I, Lazareff JA, Masterman-Smith M, Geschwind DH, Bronner-Fraser M, Kornblum HI. Cancerous stem cells can arise from pediatric brain tumors. Proc Natl Acad Sci U S A. 2003; 100(25):15178-15183. [PubMed: 14645703]

9. Singh SK, Hawkins C, Clarke ID, Squire JA, Bayani J, Hide T, Henkelman RM, Cusimano MD, Dirks PB. Identification of human brain tumour initiating cells. Nature. 2004; 432(7015):396-401. [PubMed: 15549107]

10. Reya T, Morrison SJ, Clarke MF, Weissman IL. Stem cells, cancer, and cancer stem cells. Nature. 2001; 414(6859):105-111. [PubMed: 11689955]

11. Singh SK, Clarke ID, Terasaki M, Bonn VE, Hawkins C, Squire J, Dirks PB. Identification of a cancer stem cell in human brain tumors. Cancer Res. 2003; 63(18):5821-5828. [PubMed: 14522905]

12. Al-Hajj M, Wicha MS, Benito-Hernandez A, Morrison SJ, Clarke MF. Prospective identification of tumorigenic breast cancer cells. Proc Natl Acad Sci USA. 2003; 100:3983-3988. [PubMed: 12629218]

13. Schatton T, Murphy GF, Frank NY, Yamaura K, Waaga-Gasser AM, Gasser M, Zhan Q, Jordan S, Duncan LM, Weishaupt C, et al. Identification of cells initiating human melanomas. Nature. 2008; 451(7176):345-349. [PubMed: 18202660]

14. Quintana E, Shackleton M, Sabel MS, Fullen DR, Johnson TM, Morrison SJ. Efficient tumour formation by single human melanoma cells. Nature. 2008; 456(7222):593-598. [PubMed: 19052619]

15. Boiko AD, Razorenova OV, van de Rijn M, Swetter SM, Johnson DL, Ly DP, Butler PD, Yang GP, Joshua B, Kaplan MJ, et al. Human melanoma-initiating cells express neural crest nerve growth factor receptor CD271. Nature. 2010; 466(7302):133-137. [PubMed: 20596026]

16. Ishizawa K, Rasheed ZA, Karisch R, Wang Q, Kowalski J, Susky E, Pereira K, Karamboulas C, Moghal N, Rajeshkumar NV, et al. Tumor-initiating cells are rare in many human tumors. Cell stem cell. 2010; 7(3):279-282. [PubMed: 20804964]

17. Nowell PC. The clonal evolution of tumor cell populations. Science. 1976; 194(4260):23-28. [PubMed: 959840]

18. Burrell RA, McGranahan N, Bartek J, Swanton C. The causes and consequences of genetic heterogeneity in cancer evolution. Nature. 2013; 501(7467):338-345. [PubMed: 24048066]

19. Cahill DP, Kinzler KW, Vogelstein B, Lengauer C. Genetic instability and darwinian selection in tumours. Trends in cell biology. 1999; 9(12):M57-60. [PubMed: 10611684]

20. Cairns J. Mutation selection and the natural history of cancer. Nature. 1975; 255(5505):197-200. [PubMed: 1143315]

21. Shackleton M, Quintana E, Fearon ER, Morrison SJ. Heterogeneity in cancer: cancer stem cells versus clonal evolution. Cell. 2009; 138(5):822-829. [PubMed: 19737509] 
22. Penney KL, Stampfer MJ, Jahn JL, Sinnott JA, Flavin R, Rider JR, Finn S, Giovannucci E, Sesso HD, Loda M, et al. Gleason Grade Progression Is Uncommon. Cancer Research. 2013; 73(16): 5163-5168. [PubMed: 23946472]

23. Bidlingmaier S, Zhu X, Liu B. The utility and limitations of glycosylated human CD133 epitopes in defining cancer stem cells. Journal of molecular medicine. 2008; 86(9):1025-1032. [PubMed: 18535813]

24. Clement V, Dutoit V, Marino D, Dietrich PY, Radovanovic I. Limits of CD133 as a marker of glioma self-renewing cells. Int J Cancer. 2009; 125(1):244-248. [PubMed: 19350631]

25. Griguer CE, Oliva CR, Gobin E, Marcorelles P, Benos DJ, Lancaster JR Jr. Gillespie GY. CD133 is a marker of bioenergetic stress in human glioma. PLoS One. 2008; 3(11):e3655. [PubMed: 18985161]

26. Wang J, Sakariassen PO, Tsinkalovsky O, Immervoll H, Boe SO, Svendsen A, Prestegarden L, Rosland G, Thorsen F, Stuhr L, et al. CD133 negative glioma cells form tumors in nude rats and give rise to CD133 positive cells. Int J Cancer. 2007; 122(4):761-768. [PubMed: 17955491]

27. Jaksch M, Munera J, Bajpai R, Terskikh A, Oshima RG. Cell cycle-dependent variation of a CD133 epitope in human embryonic stem cell, colon cancer, and melanoma cell lines. Cancer Res. 2008; 68(19):7882-7886. [PubMed: 18829544]

28. Bao S. Glioma stem cells promote radioresistance by preferential activation of the DNA damage response. Nature. 2006; 444:756-760. [PubMed: 17051156]

29. Pallini R, Ricci-Vitiani L, Banna GL, Signore M, Lombardi D, Todaro M, Stassi G, Martini M, Maira G, Larocca LM, et al. Cancer stem cell analysis and clinical outcome in patients with glioblastoma multiforme. Clin Cancer Res. 2008; 14(24):8205-8212. [PubMed: 19088037]

30. Zeppernick F, Ahmadi R, Campos B, Dictus C, Helmke BM, Becker N, Lichter P, Unterberg A, Radlwimmer B, Herold-Mende CC. Stem cell marker CD133 affects clinical outcome in glioma patients. Clinical cancer research : an official journal of the American Association for Cancer Research. 2008; 14(1):123-129. [PubMed: 18172261]

31. Suetsugu A, Nagaki M, Aoki H, Motohashi T, Kunisada T, Moriwaki H. Characterization of CD133+ hepatocellular carcinoma cells as cancer stem/progenitor cells. Biochem Biophys Res Commun. 2006; 351(4):820-824. [PubMed: 17097610]

32. Miki J, Furusato B, Li H, Gu Y, Takahashi H, Egawa S, Sesterhenn IA, McLeod DG, Srivastava S, Rhim JS. Identification of putative stem cell markers, CD133 and CXCR4, in hTERTimmortalized primary nonmalignant and malignant tumor-derived human prostate epithelial cell lines and in prostate cancer specimens. Cancer Res. 2007; 67(7):3153-3161. [PubMed: 17409422]

33. Phillips TM, McBride WH, Pajonk F. The response of CD24(-/low)/CD44+ breast cancerinitiating cells to radiation. J Natl Cancer Inst. 2006; 98(24):1777-1785. [PubMed: 17179479]

34. Fillmore CM, Kuperwasser C. Human breast cancer cell lines contain stem-like cells that selfrenew, give rise to phenotypically diverse progeny and survive chemotherapy. Breast Cancer Res. 2008; 10(2):R25. [PubMed: 18366788]

35. Prince ME. Identification of a subpopulation of cells with cancer stem cell properties in head and neck squamous cell carcinoma. Proc Natl Acad Sci USA. 2007; 104:973-978. [PubMed: 17210912]

36. Jaggupilli A, Elkord E. Significance of CD44 and CD24 as cancer stem cell markers: an enduring ambiguity. Clinical \& developmental immunology. 2012; 2012:708036. [PubMed: 22693526]

37. Zoller M. CD44: can a cancer-initiating cell profit from an abundantly expressed molecule? Nat Rev Cancer. 2011; 11(4):254-267. [PubMed: 21390059]

38. Kastan MB, Schlaffer E, Russo JE, Colvin OM, Civin CI, Hilton J. Direct demonstration of elevated aldehyde dehydrogenase in human hematopoietic progenitor cells. Blood. 1990; 75(10): 1947-1950. [PubMed: 2337669]

39. Ginestier C, Hur MH, Charafe-Jauffret E, Monville F, Dutcher J, Brown M, Jacquemier J, Viens P, Kleer CG, Liu S, et al. ALDH1 Is a Marker of Normal and Malignant Human Mammary Stem Cells and a Predictor of Poor Clinical Outcome. Cell stem cell. 2007; 1(5):555-567. [PubMed: 18371393] 
40. Resetkova E, Reis-Filho JS, Jain RK, Mehta R, Thorat MA, Nakshatri H, Badve S. Prognostic impact of ALDH1 in breast cancer: a story of stem cells and tumor microenvironment. Breast cancer research and treatment. 2010; 123(1):97-108. [PubMed: 19911270]

41. Marcato P, Dean CA, Pan D, Araslanova R, Gillis M, Joshi M, Helyer L, Pan L, Leidal A, Gujar S, et al. Aldehyde dehydrogenase activity of breast cancer stem cells is primarily due to isoform ALDH1A3 and its expression is predictive of metastasis. Stem Cells. 2011; 29(1):32-45. [PubMed: 21280157]

42. Bhaijee F, Pepper DJ, Pitman KT, Bell D. Cancer stem cells in head and neck squamous cell carcinoma: a review of current knowledge and future applications. Head Neck. 2012; 34(6):894899. [PubMed: 21850700]

43. Huang EH, Hynes MJ, Zhang T, Ginestier C, Dontu G, Appelman H, Fields JZ, Wicha MS, Boman BM. Aldehyde dehydrogenase 1 is a marker for normal and malignant human colonic stem cells (SC) and tracks SC overpopulation during colon tumorigenesis. Cancer Res. 2009; 69(8):33823389. [PubMed: 19336570]

44. Okudela K, Woo T, Mitsui H, Tajiri M, Masuda M, Ohashi K. Expression of the potential cancer stem cell markers, CD133, CD44, ALDH1, and beta-catenin, in primary lung adenocarcinoma-their prognostic significance. Pathology international. 2012; 62(12):792-801. [PubMed: 23252868]

45. Goldstein AS, Huang J, Guo C, Garraway IP, Witte ON. Identification of a cell of origin for human prostate cancer. Science. 2010; 329(5991):568-571. [PubMed: 20671189]

46. Vlashi E, Kim K, Lagadec C, Donna LD, McDonald JT, Eghbali M, Sayre JW, Stefani E, McBride W, Pajonk F. In vivo imaging, tracking, and targeting of cancer stem cells. J Natl Cancer Inst. 2009; 101(5):350-359. [PubMed: 19244169]

47. Lagadec C, Vlashi E, Bhuta S, Lai C, Mischel P, Werner M, Henke M, Pajonk F. Tumor cells with low proteasome subunit expression predict overall survival in head and neck cancer patients. BMC Cancer. 2014; 14(1):152. [PubMed: 24593279]

48. Lagadec C, Vlashi E, Frohnen P, Alhiyari Y, Chan M, Pajonk F. The RNA-binding protein Musashi-1 regulates proteasome subunit expression in breast cancer- and glioma-initiating cells. Stem Cells. 2014; 32(1):135-144. [PubMed: 24022895]

49. Xu H, Fu J, Ha SW, Ju D, Zheng J, Li L, Xie Y. The CCAAT box-binding transcription factor NFY regulates basal expression of human proteasome genes. Biochim Biophys Acta. 2012; 1823(4): 818-825. [PubMed: 22285817]

50. Pan J, Zhang Q, Wang Y, You M. 26S proteasome activity is down-regulated in lung cancer stemlike cells propagated in vitro. PLoS One. 2010; 5(10):e13298. [PubMed: 20949018]

51. Adikrisna R, Tanaka S, Muramatsu S, Aihara A, Ban D, Ochiai T, Irie T, Kudo A, Nakamura N, Yamaoka S, et al. Identification of pancreatic cancer stem cells and selective toxicity of chemotherapeutic agents. Gastroenterology. 2012; 143(1):234-245. e237. [PubMed: 22510202]

52. Muramatsu S, Tanaka S, Mogushi K, Adikrisna R, Aihara A, Ban D, Ochiai T, Irie T, Kudo A, Nakamura $\mathrm{N}$, et al. Visualization of stem cell features in human hepatocellular carcinoma reveals in vivo significance of tumor-host interaction and clinical course. Hepatology. 2013; 58(1):218228. [PubMed: 23447025]

53. Lagadec C, Vlashi E, Della Donna L, Dekmezian C, Pajonk F. Radiation-induced reprogramming of breast cancer cells. Stem Cells. 2012; 30(5):833-844. [PubMed: 22489015]

54. Vlashi E, Lagadec C, Vergnes L, Matsutani T, Masui K, Poulou M, Popescu R, Della Donna L, Evers P, Dekmezian C, et al. Metabolic state of glioma stem cells and nontumorigenic cells. Proceedings of the National Academy of Sciences of the United States of America. 2011; 108(38): 16062-16067. [PubMed: 21900605]

55. Elfadl D, Hodgkinson VC, Long ED, Scaife L, Drew PJ, Lind MJ, Cawkwell L. A pilot study to investigate the role of the $26 \mathrm{~S}$ proteasome in radiotherapy resistance and loco-regional recurrence following breast conserving therapy for early breast cancer. Breast. 2011; 20(4):334-337. [PubMed: 21411324]

56. Yamanaka S, Blau HM. Nuclear reprogramming to a pluripotent state by three approaches. Nature. 2010; 465(7299):704-712. [PubMed: 20535199] 
57. Greenow K, Clarke AR. Controlling the stem cell compartment and regeneration in vivo: the role of pluripotency pathways. Physiological reviews. 2012; 92(1):75-99. [PubMed: 22298652]

58. Xu H, Wang W, Li C, Yu H, Yang A, Wang B, Jin Y. WWP2 promotes degradation of transcription factor OCT4 in human embryonic stem cells. Cell Res. 2009; 19(5):561-573. [PubMed: 19274063]

59. Baltus GA, Kowalski MP, Zhai H, Tutter AV, Quinn D, Wall D, Kadam S. Acetylation of sox2 induces its nuclear export in embryonic stem cells. Stem Cells. 2009; 27(9):2175-2184. [PubMed: 19591226]

60. Chen ZY, Wang X, Zhou Y, Offner G, Tseng CC. Destabilization of Kruppel-like factor 4 protein in response to serum stimulation involves the ubiquitin-proteasome pathway. Cancer Res. 2005; 65(22):10394-10400. [PubMed: 16288030]

61. Farrell AS, Sears RC. MYC degradation. Cold Spring Harbor perspectives in medicine. 2014; 4(3)

62. Moretto-Zita M, Jin H, Shen Z, Zhao T, Briggs SP, Xu Y. Phosphorylation stabilizes Nanog by promoting its interaction with Pin1. Proc Natl Acad Sci U S A. 2010; 107(30):13312-13317. [PubMed: 20622153]

63. Nichols J, Zevnik B, Anastassiadis K, Niwa H, Klewe-Nebenius D, Chambers I, Scholer H, Smith A. Formation of pluripotent stem cells in the mammalian embryo depends on the POU transcription factor Oct4. Cell. 1998; 95(3):379-391. [PubMed: 9814708]

64. Levasseur DN, Wang J, Dorschner MO, Stamatoyannopoulos JA, Orkin SH. Oct4 dependence of chromatin structure within the extended Nanog locus in ES cells. Genes Dev. 2008; 22(5):575580. [PubMed: 18283123]

65. Liedtke S, Enczmann J, Waclawczyk S, Wernet P, Kogler G. Oct4 and its pseudogenes confuse stem cell research. Cell stem cell. 2007; 1(4):364-366. [PubMed: 18371374]

66. Liedtke S, Stephan M, Kogler G. Oct4 expression revisited: potential pitfalls for data misinterpretation in stem cell research. Biological chemistry. 2008; 389(7):845-850. [PubMed: 18627312]

67. de Resende MF, Chinen LT, Vieira S, Jampietro J, da Fonseca FP, Vassallo J, Campos LC, Guimaraes GC, Soares FA, Rocha RM. Prognostication of OCT4 isoform expression in prostate cancer. Tumour biology : the journal of the International Society for Oncodevelopmental Biology and Medicine. 2013

68. Koukourakis MI, Giatromanolaki A, Tsakmaki V, Danielidis V, Sivridis E. Cancer stem cell phenotype relates to radio-chemotherapy outcome in locally advanced squamous cell head-neck cancer. Br J Cancer. 2012; 106(5):846-853. [PubMed: 22333601]

69. Zhang X, Han B, Huang J, Zheng B, Geng Q, Aziz F, Dong Q. Prognostic significance of OCT4 expression in adenocarcinoma of the lung. Japanese journal of clinical oncology. 2010; 40(10): 961-966. [PubMed: 20462980]

70. Saigusa S, Tanaka K, Toiyama Y, Yokoe T, Okugawa Y, Ioue Y, Miki C, Kusunoki M. Correlation of CD133, OCT4, and SOX2 in rectal cancer and their association with distant recurrence after chemoradiotherapy. Annals of surgical oncology. 2009; 16(12):3488-3498. [PubMed: 19657699]

71. Boyer LA, Lee TI, Cole MF, Johnstone SE, Levine SS, Zucker JP, Guenther MG, Kumar RM, Murray HL, Jenner RG, et al. Core transcriptional regulatory circuitry in human embryonic stem cells. Cell. 2005; 122(6):947-956. [PubMed: 16153702]

72. Takahashi K, Yamanaka S. Induction of pluripotent stem cells from mouse embryonic and adult fibroblast cultures by defined factors. Cell. 2006; 126(4):663-676. [PubMed: 16904174]

73. Arnold K, Sarkar A, Yram MA, Polo JM, Bronson R, Sengupta S, Seandel M, Geijsen N, Hochedlinger K. Sox2(+) adult stem and progenitor cells are important for tissue regeneration and survival of mice. Cell stem cell. 2011; 9(4):317-329. [PubMed: 21982232]

74. Park D, Xiang AP, Mao FF, Zhang L, Di CG, Liu XM, Shao Y, Ma BF, Lee JH, Ha KS, et al. Nestin is required for the proper self-renewal of neural stem cells. Stem Cells. 2010; 28(12):21622171. [PubMed: 20963821]

75. Tsukamoto T, Mizoshita T, Mihara M, Tanaka H, Takenaka Y, Yamamura Y, Nakamura S, Ushijima T, Tatematsu M. Sox 2 expression in human stomach adenocarcinomas with gastric and 
gastric-and-intestinal-mixed phenotypes. Histopathology. 2005; 46(6):649-658. [PubMed: 15910596]

76. Li XL, Eishi Y, Bai YQ, Sakai H, Akiyama Y, Tani M, Takizawa T, Koike M, Yuasa Y. Expression of the SRY-related HMG box protein SOX2 in human gastric carcinoma. International journal of oncology. 2004; 24(2):257-263. [PubMed: 14719100]

77. Rodriguez-Pinilla SM, Sarrio D, Moreno-Bueno G, Rodriguez-Gil Y, Martinez MA, Hernandez L, Hardisson D, Reis-Filho JS, Palacios J. Sox2: a possible driver of the basal-like phenotype in sporadic breast cancer. Modern pathology : an official journal of the United States and Canadian Academy of Pathology, Inc. 2007; 20(4):474-481.

78. Sanada Y, Yoshida K, Ohara M, Oeda M, Konishi K, Tsutani Y. Histopathologic evaluation of stepwise progression of pancreatic carcinoma with immunohistochemical analysis of gastric epithelial transcription factor SOX2: comparison of expression patterns between invasive components and cancerous or nonneoplastic intraductal components. Pancreas. 2006; 32(2):164170. [PubMed: 16552336]

79. Alonso MM, Diez-Valle R, Manterola L, Rubio A, Liu D, Cortes-Santiago N, Urquiza L, Jauregi P, Lopez de Munain A, Sampron N, et al. Genetic and epigenetic modifications of Sox 2 contribute to the invasive phenotype of malignant gliomas. PLoS One. 2011; 6(11):e26740. [PubMed: 22069467]

80. Chou YT, Lee CC, Hsiao SH, Lin SE, Lin SC, Chung CH, Chung CH, Kao YR, Wang YH, Chen $\mathrm{CT}$, et al. The emerging role of SOX2 in cell proliferation and survival and its crosstalk with oncogenic signaling in lung cancer. Stem Cells. 2013

81. Zhao W, Hisamuddin IM, Nandan MO, Babbin BA, Lamb NE, Yang VW. Identification of Kruppel-like factor 4 as a potential tumor suppressor gene in colorectal cancer. Oncogene. 2004; 23(2):395-402. [PubMed: 14724568]

82. Lagadinou ED, Sach A, Callahan K, Rossi RM, Neering SJ, Minhajuddin M, Ashton JM, Pei S, Grose V, O'Dwyer KM, et al. BCL-2 inhibition targets oxidative phosphorylation and selectively eradicates quiescent human leukemia stem cells. Cell stem cell. 2013; 12(3):329-341. [PubMed: 23333149]

83. Wei D, Gong W, Kanai M, Schlunk C, Wang L, Yao JC, Wu TT, Huang S, Xie K. Drastic downregulation of Kruppel-like factor 4 expression is critical in human gastric cancer development and progression. Cancer Res. 2005; 65(7):2746-2754. [PubMed: 15805274]

84. Pandya AY, Talley LI, Frost AR, Fitzgerald TJ, Trivedi V, Chakravarthy M, Chhieng DC, Grizzle WE, Engler JA, Krontiras H, et al. Nuclear localization of KLF4 is associated with an aggressive phenotype in early-stage breast cancer. Clin Cancer Res. 2004; 10(8):2709-2719. [PubMed: 15102675]

85. Hirsch HA, Iliopoulos D, Tsichlis PN, Struhl K. Metformin selectively targets cancer stem cells, and acts together with chemotherapy to block tumor growth and prolong remission. Cancer research. 2009; 69(19):7507-7511. [PubMed: 19752085]

86. Yu J, Vodyanik MA, Smuga-Otto K, Antosiewicz-Bourget J, Frane JL, Tian S, Nie J, Jonsdottir GA, Ruotti V, Stewart R, et al. Induced pluripotent stem cell lines derived from human somatic cells. Science. 2007; 318(5858):1917-1920. [PubMed: 18029452]

87. Chen X, Whitney EM, Gao SY, Yang VW. Transcriptional profiling of Kruppel-like factor 4 reveals a function in cell cycle regulation and epithelial differentiation. Journal of molecular biology. 2003; 326(3):665-677. [PubMed: 12581631]

88. Chen X, Johns DC, Geiman DE, Marban E, Dang DT, Hamlin G, Sun R, Yang VW. Kruppel-like factor 4 (gut-enriched Kruppel-like factor) inhibits cell proliferation by blocking G1/S progression of the cell cycle. J Biol Chem. 2001; 276(32):30423-30428. [PubMed: 11390382]

89. Shields JM, Christy RJ, Yang VW. Identification and characterization of a gene encoding a gutenriched Kruppel-like factor expressed during growth arrest. J Biol Chem. 1996; 271(33):20009_ 20017. [PubMed: 8702718]

90. Eramo A, Ricci-Vitiani L, Zeuner A, Pallini R, Lotti F, Sette G, Pilozzi E, Larocca LM, Peschle C, De Maria R. Chemotherapy resistance of glioblastoma stem cells. Cell Death Differ. 2006; 13(7): 1238-1241. [PubMed: 16456578] 
91. Vlashi E, Lagadec C, Vergnes L, Matsutani T, Masui K, Poulou M, Popescu R, Della Donna L, Evers P, Dekmezian C, et al. Metabolic state of glioma stem cells and nontumorigenic cells. Proceedings of the National Academy of Sciences of the United States of America. 2011; 108(38): 16062-16067. [PubMed: 21900605]

92. Woodward WA, Chen MS, Behbod F, Alfaro MP, Buchholz TA, Rosen JM. WNT/beta-catenin mediates radiation resistance of mouse mammary progenitor cells. Proc Natl Acad Sci U S A. 2007; 104(2):618-623. [PubMed: 17202265]

93. Lagadec C, Vlashi E, Della Donna L, Meng Y, Dekmezian C, Kim K, Pajonk F. Survival and selfrenewing capacity of breast cancer initiating cells during fractionated radiation treatment. Breast Cancer Res. 2010; 12(1):R13. [PubMed: 20158881]

94. Salmina K, Jankevics E, Huna A, Perminov D, Radovica I, Klymenko T, Ivanov A, Jascenko E, Scherthan H, Cragg M, et al. Up-regulation of the embryonic self-renewal network through reversible polyploidy in irradiated p53-mutant tumour cells. Exp Cell Res. 2010; 316(13):2099_ 2112. [PubMed: 20457152]

95. Ghisolfi L, Keates AC, Hu X, Lee DK, Li CJ. Ionizing radiation induces stemness in cancer cells. PLoS One. 2012; 7(8):e43628. [PubMed: 22928007]

96. Jopling C, Boue S, Izpisua Belmonte JC. Dedifferentiation, transdifferentiation and reprogramming: three routes to regeneration. Nature reviews Molecular cell biology. 2011; 12(2): 79-89.

97. Chaffer CL, Brueckmann I, Scheel C, Kaestli AJ, Wiggins PA, Rodrigues LO, Brooks M, Reinhardt F, Su Y, Polyak K, et al. Normal and neoplastic nonstem cells can spontaneously convert to a stem-like state. Proceedings of the National Academy of Sciences of the United States of America. 2011; 108(19):7950-7955. [PubMed: 21498687]

98. Tata PR, Mou H, Pardo-Saganta A, Zhao R, Prabhu M, Law BM, Vinarsky V, Cho JL, Breton S, Sahay A, et al. Dedifferentiation of committed epithelial cells into stem cells in vivo. Nature. 2013; 503(7475):218-223. [PubMed: 24196716]

99. Shaykhiev R, Wang R, Zwick RK, Hackett NR, Leung R, Moore MA, Sima CS, Chao IW, Downey RJ, Strulovici-Barel Y, et al. Airway basal cells of healthy smokers express an embryonic stem cell signature relevant to lung cancer. Stem Cells. 2013; 31(9):1992-2002. [PubMed: 23857717]

100. Balkwill FR, Capasso M, Hagemann T. The tumor microenvironment at a glance. Journal of cell science. 2012; 125(Pt 23):5591-5596. [PubMed: 23420197]

101. Gilbertson RJ, Rich JN. Making a tumour's bed: glioblastoma stem cells and the vascular niche. Nat Rev Cancer. 2007; 7(10):733-736. [PubMed: 17882276]

102. Salcedo R, Oppenheim JJ. Role of chemokines in angiogenesis: CXCL12/SDF-1 and CXCR4 interaction, a key regulator of endothelial cell responses. Microcirculation. 2003; 10(3-4):359370. [PubMed: 12851652]

103. Shawber CJ, Das I, Francisco E, Kitajewski J. Notch signaling in primary endothelial cells. Ann N Y Acad Sci. 2003; 995:162-170. [PubMed: 12814948]

104. Fan X, Khaki L, Zhu TS, Soules ME, Talsma CE, Gul N, Koh C, Zhang J, Li YM, Maciaczyk J, et al. NOTCH pathway blockade depletes CD133-positive glioblastoma cells and inhibits growth of tumor neurospheres and xenografts. Stem Cells. 2010; 28(1):5-16. [PubMed: 19904829]

105. Heddleston JM, Li Z, McLendon RE, Hjelmeland AB, Rich JN. The hypoxic microenvironment maintains glioblastoma stem cells and promotes reprogramming towards a cancer stem cell phenotype. Cell Cycle. 2009; 8(20):3274-3284. [PubMed: 19770585]

106. Hjelmeland AB, Wu Q, Heddleston JM, Choudhary GS, MacSwords J, Lathia JD, McLendon R, Lindner D, Sloan A, Rich JN. Acidic stress promotes a glioma stem cell phenotype. Cell Death Differ. 2011; 18(5):829-840. [PubMed: 21127501]

107. Vermeulen L, De Sousa EMF, van der Heijden M, Cameron K, de Jong JH, Borovski T, Tuynman JB, Todaro M, Merz C, Rodermond H, et al. Wnt activity defines colon cancer stem cells and is regulated by the microenvironment. Nature cell biology. 2010; 12(5):468-476.

108. Giannoni E, Bianchini F, Masieri L, Serni S, Torre E, Calorini L, Chiarugi P. Reciprocal activation of prostate cancer cells and cancer-associated fibroblasts stimulates epithelial- 
mesenchymal transition and cancer stemness. Cancer research. 2010; 70(17):6945-6956. [PubMed: 20699369]

109. Iliopoulos D, Hirsch HA, Wang G, Struhl K. Inducible formation of breast cancer stem cells and their dynamic equilibrium with non-stem cancer cells via IL6 secretion. Proceedings of the National Academy of Sciences of the United States of America. 2011; 108(4):1397-1402. [PubMed: 21220315]

110. Ohanna M, Cheli Y, Bonet C, Bonazzi VF, Allegra M, Giuliano S, Bille K, Bahadoran P, Giacchero D, Lacour JP, et al. Secretome from senescent melanoma engages the STAT3 pathway to favor reprogramming of naive melanoma towards a tumor-initiating cell phenotype. Oncotarget. 2013; 4(12):2212-2224. [PubMed: 24344100]

111. Papadopoulou A, Kletsas D. Human lung fibroblasts prematurely senescent after exposure to ionizing radiation enhance the growth of malignant lung epithelial cells in vitro and in vivo. International journal of oncology. 2011; 39(4):989-999. [PubMed: 21814715]

112. Hawsawi NM, Ghebeh H, Hendrayani SF, Tulbah A, Al-Eid M, Al-Tweigeri T, Ajarim D, Alaiya A, Dermime S, Aboussekhra A. Breast carcinoma-associated fibroblasts and their counterparts display neoplastic-specific changes. Cancer research. 2008; 68(8):2717-2725. [PubMed: 18413739]

113. Chiang C-S, Hong J-H, Stalder A, Sun J-RH, Withers HR, McBride WH. Late-delayed molecular responses to brain irradiation. Int J Rad Biol. 1999

114. Chiang CS, Hong JH, Stalder A, Sun JR, Withers HR, McBride WH. Delayed molecular responses to brain irradiation. Int J Radiat Biol. 1997; 72(1):45-53. [PubMed: 9246193]

115. Cartwright P, McLean C, Sheppard A, Rivett D, Jones K, Dalton S. LIF/STAT3 controls ES cell self-renewal and pluripotency by a Myc-dependent mechanism. Development. 2005; 132(5):885896. [PubMed: 15673569]

116. Liu S, Cong Y, Wang D, Sun Y, Deng L, Liu Y, Martin-Trevino R, Shang L, McDermott SP, Landis MD, et al. Breast Cancer Stem Cells Transition between Epithelial and Mesenchymal States Reflective of their Normal Counterparts. Stem cell reports. 2014; 2(1):78-91. [PubMed: 24511467] 